\title{
Evaluation of growth, yield and nutrient content with microbial consortia combined with different organic manures in Rumex acetosella $\mathbf{L}$.
}

\author{
Sanjukta Biswas \\ Department of Botany, Biofertilizer Lab, Bangalore University, Bangalore-560056 (Karnataka)
}

\begin{abstract}
The present study was carried out to evaluate the response of microbial bioinoculants along with different organic manures (vermicompost and greencompost) on growth, yield and nutrient uptake of Rumex. Field experiments were carried out in 2010-2011 in randomized replicated block designs consisting of four replicates of each treatment. The experiment consisted of five different microbial bioinoculants combined with two organic manures. Various treatments given to Rumex were Frateuria aurentia (potassium mobilizer) Trichoderma viride (biocontrol agent), Azospirillium brasilense (Nitrogen source) and Pseudomonas fluorescens (plant growth promoting bacteria) significantly increased plant biomass, yield and nutrient content of Rumex. Results revealed that among the two organic manures vermi compost combined with bioinoculants significantly influenced the growth and nutrient uptake. Plants inoculated with vermicompost and Frateuria aurentia has recorded maximum growth.
\end{abstract}

Keywords: Bioinoculants, Frateuria, Greencompost, Rumex, Vermicompost

\section{Introduction}

Organic farming is a new agricultural production system involves locally and naturally available organic materials or agro inputs to meet out the production system without endangering our precious natural resources. In organic farming, the nutritional demands of crop are met out mainly through on farm organic wastes, biofertilizer, green manure crop and vermicompost. The excess use of chemical fertilizers has deleterious effect leading to decline in the productivity of crops resulting in non availability of micronutrients, which has become a serious threat to the environment. Organic agriculture is an important step of production methods and are supportive of environment. Organic manure works as inducer in nature and generally determined in terms of physical, chemical and biological properties of soil and crop growth. The advantages of organic manure are many and varied. Organic matter forms an important part of soil environment. Therefore, nutrients can be supplied to the soil as well as to the crop too through various organic manures and microbial bioinoculants .

Composting is a natural way of recycling of solid waste management process. They supply balanced nutrients to plant roots and stimulate growth by increasing organic matter content of the soil. Different organic sources like vermicompost and greencompost are rich in nutrient content which are the better sources for sustainable production by enhancing the crop yield and growth.

Vermicompost is an organic manure produced as the vermicast by earthworm feeding on biological waste material, plant residues [1]. Vermicompost is one of the best source of nutrients improves the physical and chemical properties of crops [2]. Due to absence of toxic enzymes, it is also eco friendly and has beneficial effect on the biochemical activities of the soil [3]. It also increases the quality, fertility, mineral content of the soil structure and at the same time enhances soil aeration, texture and jilt there by reducing soil compaction [4]. It also build up water retention capacity of soil because of its high organic matter content and promotes root growth and nutrient absorption [5].

Green manure is one of the significant sources of nutrient supply for organic crops. They improve the physical properties of soil by supplying plant nutrients and promote the biological properties of the soil . Use and management of crop residues and green manures are becoming an increasingly important aspect of environmentally sound sustainable agriculture [6]. Incorporation of green manure increased the growth and yield parameters [7]. Green manuring is a cheap and effective way of improving soil fertility and can be a boon to poor/marginal farmers who cannot afford to use chemical fertilizers due to its high cost.

Bioinoculants or microbial inoculum enhance the process of composting and enrich nutrient content to the soil. Biofertilizers combined with organic manure influences the plant growth by enhancing root biomass, total root surface facilitates higher absorption of nutrients and increase in yield by reducing consumption of natural sources of energy.The bioinoculants have proved that their application has the potential to increase the biomass and productivity of a wide range of crops [8]. 
Rumex acetosella L. generally known as "sheep sorrel" belongs to the family Polygonaceae best known for its astringent properties. It is used as antiseptic, diuretic, hepatic, depurative and diaphoretic. Hence, the present study was undertaken based on available scientific literature highlights, to determine that, different microbial bioinoculants by integrating organic manure has influenced the yield and other growth attributes in Rumex.

\subsection{Preparation of Compost}

\section{Materials and methods}

Composting were carried out by pit and heap method at Dept. of Botany, Bangalore University, Bangalore in 2010 - 2011. Organic wastes from different locations of Jnana Bharathi Campus viz., library, canteen, Gandhi Bhavan, were collected and dumped at the backyard of Botany Dept., Bangalore University, Bangalore in pits and heaps for decomposition. Vermicomposting was carried out in vermi bins at Dept. of Botany, BUB. Cement bins measuring 3 X 3 feet were filled with the half decomposed organic wastes and cow dung in the form of slurry was sprayed. The moisture content was maintained at about $60-70$ per cent and the bins were kept under shade. Earthworms Eisenia foetida were introduced into the cement bins. After a week's time, vermicastings were collected superficially and used for further studies. The bins were filled with partially decomposed organic residues as and when needed.

Gliricidia leaves were collected from in and around Bangalore University, for making green manure. Leaves of Gliricidia, soil and cow dung was mixed in equal proportion and covered with plastic sheets. Composting was done in heaps under direct sunlight for 20 days. Moisture was maintained as 30 per cent by sprinkling water every day. Later was transferred to the bins and kept in shade. After 60 days green compost was ready for further studies.

\subsection{Enrichment of Compost:}

Bioinoculants viz., Frateuria aurentia (KMB), Trichoderma viride (biocontrol agent), Azospirillum brasilense, (nitrogen source), Pseudomonas fluorescens (plant growth promoting rhizobacteria) were inoculated into compost in different combinations and the enriched compost thus obtained were used for various crop plants and the results were recorded.

\subsection{Response of Compost and Bioinoculants on Rumex acetosella $L$.}

Field experiments were carried out at Department of Botany, to evaluate the direct effect of two different organic manures viz., vermicompost and greencompost along with bioinoculants. Experiments were carried out in replicated randomized block designed with four replications for each treatments. The traditional seed variety of Rumex acetosella were used for the experiments which were procured from farmer's seed bank (Kolar and Green Foundation). Treatments given were as follows: $\mathrm{C}=$ Green Compost (G.C.), $\mathrm{T}_{1}=$ G.C. + Frateuria aurentia (F.a.), $\mathrm{T}_{2}=$ G.C. + Trichoderma viride(T.v.), $\mathrm{T}_{3}=$ G.C. + Azospirillum brasilense(A.b.), $\mathrm{T}_{4}=$ G.C. + Pseuodomonas fluorescens (P.f.), and for vermicompost treatments are as follows: $\mathrm{C}=$ VermiCompost alone (V.C.), $\mathrm{T}_{1}=$ V.C. + Frateuria aurentia (F.a.), $\mathrm{T}_{2}=$ V.C. + Trichoderma viride(T.v.), $\mathrm{T}_{3}=$ V.C. + Azospirillum brasilense(A.b), $\mathrm{T}_{4}=$ V.C. + Pseuodomonas fluorescens $(P . f$.$) .$

Treatments were given at $15^{\text {th }}$ and $45^{\text {th }}$ days of plants growth and harvested at $25^{\text {th }}$ and $55^{\text {th }}$ days. The following parameters were recorded : Plant growth and biomass, nutrients content viz., calcium, magnesium and phosphorus.

\subsection{Estimation of nutrient content in Rumex acetosella $\mathrm{L}$.}

Calcium and magnesium content were estimated by EDTA Titration method. Phosphorus content was estimated by following the standard method

\subsection{Growth parameters}

\section{Results and Discussion}

The field experimental treatments has influenced the growth parameters of Rumex. Among the two organic manures combined with bioinoculants applied, vermicompost was found to be the best. It has significantly increased growth yield and leaf biomass. $\mathrm{T}_{1}$ inoculated with Frateuria aurentia was found to be the superior and effective in increasing growth parameters and other yield attributes, followed by $\mathrm{T}_{2}$ and $\mathrm{T}_{4}$ respectively (Table-1). However, it remains statistically at par with application of other treatments. More dry matter accumulation might be due to beneficial effect of vermicompost and potassium. The influence of microbial enriched vermicompost recorded better root proliferation. KMB enriched compost exerted marked 
increase in shoot length, root length, highest branches, flowers and fruits development[9] The highest fruit and seed yield was achieved through application of vermicompost combined with Azotobacter [10]. Similarly, significant higher grain yield, nutrient and protein content was influenced through the application of vermi compost alone over non organic manure [11]. Vermicompost application along with biofertilizers (Azotobacter \& Phosphate Solubilizing Bacteria) significantly enhanced yield attributes [12]. Application of vermicompost @ $10 \mathrm{t} /$ ha recorded highest yield and growth parameters [13].

Table-1 Influence of Microbial Enriched Vermicompost on Growth Parameters of Rumex acetosella L.

\begin{tabular}{|c|c|c|c|c|c|c|c|c|c|c|}
\hline \multirow{3}{*}{ Treatments } & \multicolumn{10}{|c|}{ Plant Growth (Days) } \\
\hline & \multicolumn{5}{|c|}{15} & \multicolumn{5}{|c|}{45} \\
\hline & \begin{tabular}{|lr} 
R. L. \\
$(\mathrm{cm})$
\end{tabular} & $\begin{array}{|ll|}\mathrm{S} & \mathrm{L} . \\
(\mathrm{cm}) & \\
\end{array}$ & \begin{tabular}{|l} 
No. of \\
Leaves
\end{tabular} & $\begin{array}{l}\text { F.W } \\
(\mathrm{g})\end{array}$ & \begin{tabular}{|l}
$\begin{array}{l}\text { D.W. } \\
(\mathrm{g})\end{array}$ \\
\end{tabular} & $\begin{array}{ll}\text { R. L. } \\
(\mathrm{cm})\end{array}$ & \begin{tabular}{|ll}
$\mathrm{S}$ & $\mathrm{L}$. \\
$(\mathrm{cm})$ & \\
\end{tabular} & \begin{tabular}{|l|} 
No. of \\
Leaves
\end{tabular} & \begin{tabular}{|l}
$\begin{array}{l}\text { F.W } \\
(\mathrm{g})\end{array}$ \\
\end{tabular} & \begin{tabular}{|l}
$\begin{array}{l}\text { D.W. } \\
(\mathrm{g})\end{array}$ \\
\end{tabular} \\
\hline $\mathrm{T}_{1}$ & 12 & 18.3 & 28.2 & 28.2 & 1.7 & 78.5 & 33.2 & 435.7 & 1448.7 & 150.75 \\
\hline $\mathrm{T}_{2}$ & 10.3 & 16.2 & 25.7 & 22.2 & 1.0 & 74.3 & 31.8 & 328.2 & 1308.2 & 137.25 \\
\hline $\mathrm{T}_{3}$ & 9.7 & 14.1 & 21.2 & 23.3 & 1.0 & 69.0 & 26.7 & 275.0 & 1175.2 & 123.75 \\
\hline $\mathrm{T}_{4}$ & 9.3 & 16.4 & 15.0 & 13.2 & .47 & 69.8 & 22.1 & 305.2 & 1283 & 142.25 \\
\hline $\mathrm{C}$ & 8.2 & 11.2 & 11.2 & 11.2 & .35 & 55.6 & 15.0 & 133.7 & 169.2 & 30.50 \\
\hline $\mathrm{SEM} \pm$ & 0.3126 & 0.3462 & 0.658 & 0.5687 & 0.1620 & 1.6805 & 1.4844 & 9.017 & 47.869 & 5.9104 \\
\hline CD@5\% & 0.5487 & 0.6072 & 1.1542 & 0.9970 & 0.2853 & 2.9459 & 2.6022 & 15.8066 & 83.9178 & 10.3613 \\
\hline
\end{tabular}

The data in respect on growth parameters as influenced by various treatments are presented in Table -2 . Different treatments in combination with greencompost and microbial bioinoculants showed positive effects. Significantly maximum growth was recorded in $\mathrm{T}_{1}$ i.e. potassium mobilizer combined with greencompost. Maximum root length $(22.2 \mathrm{~cm})$, shoot length $(43.1 \mathrm{~cm})$, number of leaves $(152.75)$, fresh weight $(903.7 \mathrm{~g})$ and dry weight $\left(43.5 \mathrm{~g}\right.$ ) was recorded in $\mathrm{T}_{1}$ (Frateuria aurentia) treated plants than control and other treatments in both 15 and 45 day old plants. Other treatments which also influenced the growth and yield were $T_{2}$ and $T_{3}$. The combination of microbial biofertilizer along with bio manures gave maximum growth. The growth attributes might have been influenced by the application of organic manure (green manure) and biofertilizers. Green manuring with different legume crops has positive effect on growth and plant biomass [14]. Incorporation of green manure (Vigna radiata) in soil also increased soil nutrients and yield [15].

Table - 2 Influence of Microbial Enriched Greencompost on Growth Parameters of Rumex acetosella $\mathbf{L}$.

\begin{tabular}{|c|c|c|c|c|c|c|c|c|c|c|}
\hline \multirow{3}{*}{ Treatments } & \multicolumn{10}{|c|}{ Plant Growth (Days) } \\
\hline & \multicolumn{5}{|c|}{15} & \multicolumn{5}{|c|}{45} \\
\hline & $\begin{array}{ll}\text { R. L. } \\
(\mathrm{cm})\end{array}$ & $\begin{array}{ll}\mathrm{S} & \mathrm{L} . \\
(\mathrm{cm})\end{array}$ & $\begin{array}{l}\text { No. of } \\
\text { Leaves }\end{array}$ & $\begin{array}{l}\text { F.W } \\
\text { (g) }\end{array}$ & $\begin{array}{l}\text { D.W. } \\
\text { (g) }\end{array}$ & $\begin{array}{ll}\text { R. } & \text { L. } \\
(\mathrm{cm})\end{array}$ & $\begin{array}{ll}\begin{array}{l}\text { S } \\
(\mathrm{cm})\end{array} & \mathrm{L} . \\
\end{array}$ & $\begin{array}{l}\text { No. of } \\
\text { Leaves }\end{array}$ & $\begin{array}{l}\text { F.W } \\
(\mathrm{g})\end{array}$ & $\begin{array}{l}\text { D.W. } \\
(\mathrm{g})\end{array}$ \\
\hline $\mathrm{T}_{1}$ & 11.5 & 17.0 & 27.2 & 26.25 & 2.75 & 22.2 & 43.1 & 152.75 & 903.7 & 43.5 \\
\hline $\mathrm{T}_{2}$ & 11.3 & 14.5 & 22.5 & 20.27 & 1.0 & 15.2 & 42.9 & 94.75 & 767.5 & 41.6 \\
\hline $\mathrm{T}_{3}$ & 8.7 & 13.1 & 23.7 & 20.35 & 1.0 & 19.2 & 38.4 & 91.00 & 667.5 & 35.0 \\
\hline $\mathrm{T}_{4}$ & 8.3 & 10.3 & 12.5 & 11.32 & .575 & 19.5 & 33.0 & 58.50 & 402.5 & 26.5 \\
\hline $\mathrm{C}$ & 4.0 & 8.2 & 10.5 & 8.25 & .375 & 17.7 & 34.8 & 63.50 & 358.2 & 25.7 \\
\hline $\mathrm{SEM} \pm$ & 0.4419 & 0.7721 & 0.940 & 0.5711 & 0.1658 & 0.7196 & 2.2544 & 3.677 & 22.221 & 1.9291 \\
\hline CD@5\% & 0.7751 & 1.3539 & 1.6477 & 1.0009 & 0.2907 & 1.2617 & 3.9521 & 6.4450 & 38.956 & 3.3818 \\
\hline
\end{tabular}

\subsection{Nutrient Content}

Maximum available mineral nutrients were recorded with different microbial inoculants enriched with two different organic wastes (manure). The data presented in Table-3 indicated that the treatment involving vermicompost and greencompost showed highest $\mathrm{Ca}, \mathrm{Mg}, \mathrm{P}$, uptake. Significant variations were observed in vermicompost treated Rumex plants in regard to nutrient uptake. Where as, highest total uptake of nutrients (Calcium, Magnesium and Phosphorus) was observed in $T_{2}$ and $T_{3}$ treatments in both 15 days and 45 days old Rumex plants incorporated with green compost. The increased uptake of nutrients may be due to higher availability of the combined application of organic manure and bioinoculants. 
Evaluation of growth, yield and nutrient content with microbial consortia combined with different

Table -3 Influence of Microbial Enriched Composts on Nutrient Uptake of Rumex acetosella L .

\begin{tabular}{|c|c|c|c|c|c|c|c|c|c|c|c|c|}
\hline \multirow{2}{*}{ Treatments } & \multicolumn{6}{|c|}{ Vermicompost } & \multicolumn{6}{|c|}{ Greencompost } \\
\hline & \begin{tabular}{|l}
$\mathrm{Ca}$ \\
$(\mu \mathrm{g} / \mathrm{g})$ \\
\end{tabular} & \begin{tabular}{|l}
$\mathrm{Mg}$ \\
$(\mu \mathrm{g} / \mathrm{g})$
\end{tabular} & $\mathrm{P}(\mu \mathrm{g} / \mathrm{g})$ & \begin{tabular}{|l}
$\mathrm{Ca}$ \\
$(\mu \mathrm{g} / \mathrm{g})$
\end{tabular} & $\begin{array}{l}\mathrm{Mg} \\
(\mu \mathrm{g} / \mathrm{g})\end{array}$ & $\mathrm{P}(\mu \mathrm{g} / \mathrm{g})$ & $\begin{array}{l}\mathrm{Ca} \\
(\mu \mathrm{g} / \mathrm{g})\end{array}$ & $\begin{array}{l}\mathrm{Mg} \\
(\mu \mathrm{g} / \mathrm{g})\end{array}$ & $\mathrm{P}(\mu \mathrm{g} / \mathrm{g})$ & $\begin{array}{l}\mathrm{Ca} \\
(\mu \mathrm{g} / \mathrm{g}) \\
\end{array}$ & \begin{tabular}{|l}
$\begin{array}{l}\mathrm{Mg} \\
(\mu \mathrm{g} / \mathrm{g})\end{array}$ \\
\end{tabular} & $\mathrm{P}(\mu \mathrm{g} / \mathrm{g})$ \\
\hline $\mathrm{T}_{1}$ & 1.72 & 5.22 & 21.0 & 2.52 & 7.32 & 42.5 & 5.47 & 2.22 & 11.0 & 6.22 & 4.75 & 39.5 \\
\hline $\mathrm{T}_{2}$ & 1.12 & 8.17 & 10.2 & 5.82 & 6.02 & 35.5 & 3.17 & 1.72 & 26.7 & 8.52 & 8.57 & 40.2 \\
\hline $\mathrm{T}_{4}$ & 2.47 & 10.1 & 15.0 & 3.05 & 3.77 & 41.2 & 2.42 & 4.22 & 10.7 & 6.50 & 6.40 & 43.5 \\
\hline $\mathrm{C}$ & 4.55 & 4.35 & 10.2 & 7.10 & 6.75 & 20.7 & 1.40 & 2.55 & 5.25 & 5.60 & 5.57 & 30.5 \\
\hline $\mathrm{SEM} \pm$ & 0.2035 & 0.1211 & 0.639 & 0.5276 & 0.6807 & 2.177 & 0.0880 & 0.1390 & 0.547 & 0.632 & 0.6699 & 1.1328 \\
\hline CD@5\% & 0.3571 & 0.2110 & 1.1204 & 0.8904 & 1.1934 & 3.8172 & 0.1518 & 0.2448 & 0.9601 & 1.1087 & 1.9860 & 1.1746 \\
\hline
\end{tabular}

Application of vermicompost significantly enhanced the total N, P and K uptake over no organic manure [16]. Different organic treatments has significantly influenced the physico-chemical properties and nutrient availability in soil after harvest [17]. Similarly, application of organic manures and biofertilizers had significantly influenced the growth, yield and quality [18]. Dual inoculation with biofertilizers viz., Rhizobium + Azotobacter + PSB + FYM and application of FYM has significantly increased plant growth, grain yield and total N,P,K uptake [19]. Uptake of nutrients were significantly influenced by the application of manures, FYM and biofertilizers to soil, either alone or in combination [20]. Vermicompost is the best organic manure and is a low cost technology system for wastes utilization [21].

Combined inoculation of Azospirillum, Phosphate solubilizer along with EM and organic manure and vermicompost gave maximum growth [22]. Application of vermicompost considerably increased the net production rate, chlorophyll and carotenoid content. Dehydrogenase activity were also increased with the application of vermicompost [23]. Incorporation of different combinations of organic materials viz., FYM \& wheat residue, biofertilizer and vermicompost along with biofertilizers has been influenced in grain yields by 51-58 per cent [24]. In situ incorporation of green manure recorded higher values of growth parameters [25] Different treatments with organic manures and biofertilizers significantly improved the soil health, fruit quality, yield, leaf mineral and microbial population of rhizosphere soil [26].

Depending upon the composition of different composts in combination with bioinoculants as a sole source of N,P,K, the experiments were carried out. In the present study, significant increase in plant growth may be due to higher availability of Potassium through application of Potassium-mobilizer(Frateuria aurentia). Consistant statistically SEM and CD values among treatments is with great variables were noticed for optimum yield and quality.

\section{Conclusion}

Compost is often the most economical source. The manipulation of factors for composting is done mainly to enhance the microbial activity, where the rate of decomposition of organic wastes is enhanced. Microbial inoculants enhance the process of composting on the nutrient content of the finished product. The enriched compost through microbial inoculants had higher nutrient content there by enhance the crop yield. Biofertilizers being essential components of organic farming play vital role in maintaining long term soil fertility and sustainability by mobilizing fixed macro and micro nutrients or convert insoluble phosphorus in the soil into forms available to plants, thereby increasing their efficiency and availability. Currently there is a gap of plant nutrients between removal of crops and supplying through chemical fertilizer. In this context, organic manures and microbial bioinoculants would be the viable option for farmers to increase productivity per unit area. Therefore, a sound planning and management is required. The role of biofertilizers will be significant in such management plans. In this view, the established facts observed and the work carried out are presented and discussed.

\section{Acknowledgements}

The Ph.D. scholar is grateful to UGC, New Delhi, for providing financial assistance as Rajiv Gandhi National Fellowship to carry out the research work.

\section{References}

[1] M.S.Rathore, M.Singh, D.Panwar and N.S.Shekhawat, Vermicomposting: Towards Clean And Green Farming Green Farming, Vol$1(1), 2007,28-30$.

[2] S.L.Tolanur, Effect of Compost, Vermicompost, FarmYard Manure, Green Manuring and Fertilizer Nitrogen on Yield and Uptake of Major Nutrients by Rabi-Sorghum in Vertisol, Agric.Sci.Digest, 29(1), 2009, 60-62. 
[3] J. Sinha, C. K. Biswas, A. Ghosh and A. Saha, Efficacy of Vermicompost Against Fertilizers on Cicer and Pisum and on Population diversity of Nitrogen Fixing Bacteria, Journal of Environmental Biology, 31, 2010, 287-292.

[4] M.S.Ali and M.S.Jahan,Final Completion report on Coordinateproject of vermiculture:Production of Vermicompost and its use inUpland and Horticultural Crops, BARC., Dhaka, 2001,21.

[5] F.Nourbaksh, Influence of vermicomposting on Soil Waste Decomposition Kinetics in Soils, J. Zhejiarg Univ.Sci., 8, 2007, 725730 .

[6] J.Timsina and D.J.Connor, Productivity and Management of Rice-Wheat Systems. Issues and Challenges, Field Crops Res., 69, 2001, 93-112.

[7] M. Hemalatha, V.Thirumurugan and R.Balasubramanian, Effect of Organic Sources of Nitrogen on Productivity, Quality of Rice (Oryza sativa L.) and Soil Fertility in Single Crop Wetlands. Indian J. Agron, 45, 2000,564-567.

[8] J. Yadav and A.K.Yadav, Isolation and Characterization of Plant Growth Promoting Rhizobacteria for Multiple Use as Composite Biofertilizer in Organic Crop Production, Biofertilizer Newsletter, 19(1), 2011, 10-16.

[9] K.Chandra, NPK-Liquid Biofertilizers (Poly culture), (Book: Regional Centre of Organic Farming, Bangalore, 2009).

[10] K.S.Thakur,R. Thakur and Y.R.Shukla, Effect of Organic Manures and Biofertilizers on Fruit and Seed Yield of Tomato (S.lycopersicum), Green Farming, 3 (1),2012, 45-47.

[11] O. Meena, H.R.Khafi, M.A. Seikh, A. C.Mehta and B.K.Davda, Effect of Vermicompost and Nitrogen on Content, Uptake and Yield of Rabi Maize, Journal of Crop. Res., 33 (1,2 \&3), 2007, 53-54.

[12] K. Nag and A.K.Singha Roy, Residual Effect of Vermicompost, Chemical Fertilizer and Biofertilizer in Wheat (Triticum aestivum) on Succeeding Fodder Cowpea (Vigna unguiculata), Ann.Agric. Res.New Series, 29 (1,2,3 \&4), 2008, 73-77.

[13] T.Prabhakar Reddy, G.Padmaja andP.Chandrasekhar Rao, Integrated Effect of Vermicompost and Nitrogen Fertilizers on Soil Nutrient Status and Yield of Onion-radish Cropping System, Crop Res. 41 (1,2\&3),2011, 148-155.

[14] A.Mondal and A.K.Pal, Growth of Roots and Yield as Influenced by Green Manuring in Rice-Wheat Cropping System, Agric.Sci.Digest, 29(1),2009, 32-35.

[15] A.LalitaKumari, Effect of Green Manuring In Situ on Yield, Nutrient Uptake and Soil Available Nutrients in Chilli (Capsicum annuиm),2010, 1(6), 604-605.

[16] Ghanshyam, Rakesh Kumar and R.K.Jat, Productivity and Soil Fertility as Effected by Organic Manures and Inorganic Fertilizers in Greengram (Vigna radiate) - Wheat (Triticum aestivum) System Indian Journal of Agronomy, 55 (1), 2010, 16-21.

[17] P.S. Patel, B.N. Kolambe, T.U .Patel and H.M. Patel, Effect of Different Organic Manures on Growth, yield, Nutrient Uptake and Soil Properties of Bananacv. Grand Nain, The Andhra Agric. Journal, 57(3), 316-319.

[18] T.G.Mulani, A.M.Musmade, P.P.Kadu and K.K.Mangave, Effect of Organic Manures And Biofertilizers On Growth, Yield And Quality Of Bitter Gourd (Memordica charantia L.) CV. Phule Green Gold, Journal of Soils \& Crops, 18(1),2008, $258-261$.

[19] S.R.Singh, Ummed Singh and J.K.Singh, Effect of Bioinoculants and FYM on Growth, Yield and Quality of Soyabean( Glycine max) Under Rainfed Conditions of Kashmir Valley, ), Ann.Agric.Res., 30(3\&4), 2009, 87-90.

[20] B.P.Sunitha, H.C.Prakasha and K.T.Gurumurthy, Influence of Organics, Inorganics and Their Combinations on Availability, Content and Uptake of Secondary Nutrients by Rice Crop(Oryza sativa L.) in Bhadra Commend ,Karnataka, Mysore Journal of Agricultural Science, 44(3),2010, 509-516.

[21] S.Shewetha, J.Narayana, B.V.Shwetha and K.Girish, Effect of Vermicompost on Soil Bacterial and Fungal Populations in RiceCrop (Oryza sativa L.), Mysore Journal of Agricultural Science, 45(1), 2011, 7-10.

[22] R.Thenmozhi, Rejina K.,K.Madhusudhanan, A.Nagasathya, Study on Effectiveness of Various Biofertilizers on the Growth \& Biomass Production of Selected Vegetables", Research Journal of Agriculture and Biological Sciences, 6(3), 2010, $296-301$.

[23] B.Uma and M.Malathi, Vermicompost as a Soil Supplement to Improve Growth and Yield of Amaranthus species, Research Journal of Agriculture and Biological Sciences, 5(6),2009, 1054-1060.

[24] M.R.Davari and S.N. Sharma, Effect of Different Combinations of Organic Material and Biofertilizers on Productivity, Grain Quality and Economics in Organic Farming of Basmati Rice (Oryza sativa L.), Indian Journal of Agronomy, 55, 2010, 290-294.

[25] H. H.Deshpande and P. Devasenapathy, Effect of different Organic Sources of Nutrients and Green Manure on Growth and Yield Parameters of Rice (Oryza sativa L.), Grown Under Lowland Condition, Crop Res., 41 (1,2 \&3),2011, 1-5.

[26] P.Dutta, S.Biswas and S.Kundu, Effect of Organic Manures and Biofertilizers on Production of Organic Litchi, Journal of Ecofriendly Agriculture, 6 (1),2011, 13-15. 